\title{
Gastric Non-Hodgkin Lymphoma
}

National Cancer Institute

\section{Source}

National Cancer Institute. Gastric Non-Hodgkin Lymphoma. NCI Thesaurus. Code C27235.

An extranodal non-Hodgkin lymphoma that arises from the stomach with the bulk of the mass located in the stomach. The vast majority of cases are diffuse large B-cell lymphomas and B-cell lymphomas of the mucosa-associated lymphoid tissue. 